\title{
THE GROUNDS AND PROCEDURE OF THE INTEGRITY TEST OF EMPLOYEES OF THE NATIONAL ANTI-CORRUPTION BUREAU OF UKRAINE
}

Purpose - to determine the legal and factual grounds for the integrity test of employees of the National Anti-Corruption Bureau of Ukraine, to formulate the stages of this procedure. Methods. This research was done by using general and special methods of scientific cognition. With the help of abstraction methods, analysis and synthesis the author managed to identify the grounds and stages of implementation of this phenomenon by rejecting the insignificant peculiarities of the integrity test. Dialectical and logical methods allowed clarifying the essence of factual and legal grounds for the integrity test, to specify the list of concepts. Using forecasting and modeling, the author has proposed a specific model of legal regulation of the grounds and procedure for the integrity test of employees of the National AntiCorruption Bureau of Ukraine.

Results. Legal (regulatory) and factual (material) grounds for the integrity test of employees of the National Bureau are examined in this article. It is identified that the legal (regulatory) ground is, in fact, the legislative permission for the integrity test. The definition of the factual (material) ground for the test was suggested to be a certain legal fact that causes the necessity for an integrity test by the Department of Internal Control of the National Bureau.

The testing procedure of employees of the National Bureau has been defined.

Conclusions. The scientific research showed that now there are no proper legal grounds for conducting the integrity test of employees of the National Bureau, as the legal grounds for conducting the integrity test in the National Bureau are stated in the internal document. At the same time, the author has improved the factual grounds for conducting the integrity test. It was suggested to establish a procedure of the integrity test, which will consist of 10 stages in a separate section of the Law of Ukraine "On the National Anti-Corruption Bureau of Ukraine".

Key words: integrity check, public service, administrative control, simulation of situation, non-integrity behavior. 
Olesia Braverman, Postgraduate Student at the Department of Public Administration and Management of the National Academy of Internal Affairs, Senior Detective at the Division of Internal Investigation of the Department of Internal Control of the National AntiCorruption Bureau of Ukraine

orcid.org/0000-0003-06386576o.rybak30@gmail.com

\section{Introduction}

Recent events in the country show that clear regulation and consolidation is required by every action implemented by law enforcement authorities or national security and defense agencies, that can cause significant interference in human and civil rights and freedoms or their significant or long-term restriction. As evidenced in practice of the European Court of Human Rights, this is a prior issue that becomes the subject of litigation and research: were there legal and factual grounds for taking any kind of action, thus the following issue is being examined: have the official duties been exceeded while choosing the reacting form.

In total, there were 53 integrity tests conducted by The Department of Internal Control among employees of the National Anti-Corruption Bureau of Ukraine, 3 of them showed negative result (5.6\% of the total number of tests). (Reports on the work of the National AntiCorruption Bureau during 2015-2019 years).

The shown statistics signifies the necessity of improving the grounds and procedure of conducting the integrity test by the Department of Internal Control of the National Bureau.

However, nowadays, the integrity test of employees of the National Anti-Corruption Bureau of Ukraine has not been the subject of research by either domestic or foreign scientists due to the specifics of the its subject.

The purpose of this article is to determine legal and factual grounds for the integrity test of employees of the National Anti-Corruption Bureau of Ukraine, to formulate the stages of this procedure.

This research was done by using general and special methods of scientific cognition. With the help of abstraction methods, analysis and synthesis the author managed to identify the grounds and stages of implementation of this phenomenon by rejecting the insignificant peculiarities of the integrity test. Dialectical and logical methods allowed clarifying the essence of factual and legal grounds for the integrity test, to specify the list of concepts. Using forecasting and modeling, the author has proposed a specific model of legal regulation of the grounds and procedure for the integrity test of employees of the National AntiCorruption Bureau of Ukraine. 
The research tasks of this article are: 1) to study the legal (regulatory) and factual (material) grounds for the integrity test of employees of the National Bureau; 2) to define the procedure for the integrity test of employees of the National Bureau and to analyze its stages.

\section{The legal and factual grounds for the integrity test}

The legal (regulatory) ground answers the question whether the integrity test is allowed by the legislator at all, who is the subject and the object of such test, their rights and duties during its conduct, etc.

At the present moment, the integrity test is mentioned only in the Law of Ukraine "On the National Anti-Corruption Bureau of Ukraine", however, it's not clearly regulated, and the definition of integrity, integrity test, the procedure of the test and its components are not defined.

In particular, the person is being informed about the possible conduction of the integrity test and monitoring of his lifestyle while being appointed to an office in the National Bureau (The Law of Ukraine "On the National Anti-Corruption Bureau of Ukraine", 2014).

The internal control devision of the National Bureau is obliged to conduct integrity tests of employees of the National Bureau and monitoring of their lifestyle (The Law of Ukraine "On the National Anti-Corruption Bureau of Ukraine", 2014).

At the same time, legal grounds for conducting the integrity test in the National Bureau are not provisioned in a separate interdepartmental document, but in Section VII of the Regulation on the Department of Internal Control of the National Anti-Corruption Bureau of Ukraine, approved by the National Bureau Director's Order dated November $29^{\text {th }}, 2019$ by № 142 . But this is completely unacceptable, because it leads to full discretion of the Director of the National Anti-Corruption Bureau of Ukraine and the head of the internal control devision in determining the procedure of the integrity test, its grounds, improvised change and determination of these legal instruments of administrative control by the employer, that is an excessive interference in the rights and freedoms of employees of the National Bureau, together with the principle of legal certainty violation.

Therefore, we think that currently there is no proper legal basis for the application of the integrity test by the National Anti-Corruption Bureau of Ukraine.

According to the abovementioned, it should be noted that such significant restrictions on human rights and freedoms which are being experienced by an employee of the National Anti-Corruption Bureau of Ukraine during the integrity test and according to our opinion must be regulated in a legislative and regulatory act. It is unacceptable for the mentioned way of interfering in private life, grounds, order of its application and limits to be determined by internal documents exclusively.

As for the factual (material) basis for the test conduction, it involves a certain legal fact that rises the need for conducting the integrity test by the Department of Internal Control of the National Bureau. 
The law does not establish the factual (material) basis for conducting the integrity test.

After analyzing the provisions, according to which a person is notified of the possible conduction of the integrity test and lifestyle monitoring while being appointed to an office in the National Bureau (The Law of Ukraine "On the National Anti-Corruption Bureau of Ukraine", 2014), and the provisions, that the simulation of the situation is carried out with the permission of the Head of the Department of Internal Control on the basis of an official note from an employee of the Department, who received information indicating the possibility of non- integrity behavior of an employee of the National Bureau (The Regulation on the Department of Internal Control of Anti-Corruption Bureau of Ukraine, 2019), the following factual (material) grounds for the integrity test should be identified: 1) notification of the employee of the National Bureau on the possibility of conducting the integrity test while his appointment to an office; 2) receiving the information indicating the possibility of non- integrity behavior of the employee of the National Bureau by the employee of the Department of Internal Control of the National Bureau; 3) the permission of the Head of the Department of Internal Control for such test.

One should pay attention to two issues that help to understand whether there is a factual (material) ground for conducting the integrity test such as a notification of an employee of the National Bureau about the possible conduction of such test while being appointed to an office. Thus, we think that the specified notification should be in written with the particular mark of the newly appointed person about his familiarization with the content of such notification.

The second issue to pay attention to is the time limit of such notification, namely while being appointed to an office. In our opinion, it would be a logical legislative continuation, and in case of refusal to get acquainted with the signature with the notification about the possibility of conducting the integrity test, this employee cannot be appointed to the position.

Also there are uncertain legal consequences in case if an employee of the National Bureau is informed about the possible conduction of the integrity test on him not in the process of appointment, but after it. By our opinion, such issues require legislative regulation.

Let's consider the following factual (material) ground for conducting the integrity test, namely receiving the information by an employee of the Department of Internal Control of the National Bureau that indicates the possible non-integrity behavior of an employee of the National Bureau.

It should also be mentioned that the stated formulation does not exclude abuse of discretion on the part of workers of the Department of Internal Control, who can be guided by antipathy relations with particular workers of the National Bureau, which could have been formed during the performance of other duties, and due to that they knowingly declare false information in such official note of the possible non-integrity behavior of a particular worker. 
We think that the ground for the integrity testing of workers of the National Bureau could be determination of information about possible non-integrity behavior of a particular employee of the National Bureau, received by the Department of Internal Control by phone, post, e-mail, or found during an official investigation, pre-trial investigation or criminal intelligence and is executed by a relevant official note with documentary evidence. That is, in case of need or doubt in the impartiality of the particular employee of the internal control division of the National Bureau, it could be possible to check the accuracy of such information and to prevent abuse of rights by the workers of the Department.

The next factual (material) ground for conducting the integrity test is the permission of the Head of the Department of Internal Control for such test.

However, at the present moment such form of administrative document as a permit is regulated neither by laws of Ukraine "On the National Anti-Corruption Bureau of Ukraine", "On Civil Service", nor internal documents of the National Bureau.

Therefore, there would be more appropriate formulation as that the Head of the Department of Internal Control gives a written proxy as a corresponding resolution on conducting the integrity test, that is brought into accordance with the provisions of internal documents (The Instructions on office management in the National Anti-Corruption Bureau of Ukraine, 2019).

It is also impossible not to pay attention to the presence of corruption risk and possible abuse by the head of the internal control division of the National Bureau, who has the right not to give such permission, even if there are reasonable grounds for the integrity test of a particular worker of the National Bureau. Herewith, any mechanism for appealing this decision is absent, as well as external control for ensuring objectivity and impartiality of such discretionary powers' realization.

Considering the abovementioned it would be reasonable to create special law provisions which will empower workers of the Department of Internal Control to appeal both giving the permit and refusing to issue a permit for the integrity test on the basis of all collected materials to the Director of the National Bureau, who would make a final decision, according to the results of acquaintance and analysis of the materials collected by the complainant.

\section{The procedure of conducting the integrity test of employees of the National}

\section{Bureau}

The procedure of conducting the integrity test of employees of the National Bureau is a legally defined sequence of actions of the worker of the internal control division of the National Bureau empowered for such testing, united for the single purpose to check the integrity of a particular worker of the National Bureau.

The procedure as well as grounds for conducting the integrity test of employees of the National Bureau were regulated exclusively in Section VII of The Regulation on the Department of Internal Control of the National Anti-Corruption Bureau of Ukraine, approved by the order of the Director of the National Bureau dated November $29^{\text {th }}, 2019$ by № 142. 
Thus, during the simulation of situations the employees of the Department of Internal Control may use special things and documents, including specially made ones, involvement of other employees of the National Bureau and voluntary assistance of others.

Areporting notice based on the results of the integrity test, is prepared and addressed to the Director of the National Bureau, which also reflects the content of the conducted events, their results and the suggestions of the Department of Internal Control.

It is forbidden to simulate the situations in order to bring an employee of the National Bureau to criminal or administrative liability (The Regulation on the Department of Internal Control of the National Anti-Corruption Bureau of Ukraine, 2019).

At this point, unfortunately, any statutory regulation of the procedure for conducting the integrity test in the National Bureau is over.

That is why we think that it is appropriate to establish a procedure for conducting the integrity test in a separate section of the Law of Ukraine "On the National AntiCorruption Bureau of Ukraine".

Thus, the first stage of this test should be the collection and processing of data on each employee of the National Bureau in order to identify information that may indicate his moral, business and professional qualities; obligations that to some extent might affect his performance of official duties, objectivity and impartiality in decision-making; circle of contacts, family ties; lack of efficiency; feedback from management and colleagues at the previous place of work; information from the relevant state registers on the participation of an employee of the National Bureau in court proceedings and criminal proceedings in another role rather than provided in the job description; information on crossing of the state border, etc.

In addition, it is appropriate to initiate the integrity test based on the results of identifying information about the possibility of non-integrity behavior of a particular employee of the National Bureau, sent to the Department of Internal Control by phone, post, e-mail, established by an employee of the Department during the pretrial investigation or in the course of criminal intelligence and executed by a relevant official note with documentary evidence.

Therefore, the next stage of conducting the procedure of integrity test is making an official note that includes information about possibility, risk, disposition of a particular employee or employees of the National Bureau to non-integrity behavior.

Documents confirming the possibility of non-integrity behavior of an employee of the National Bureau are attached to the official note. These may be a declaration of a person authorized to perform state or local government functions for the relevant period, a complaint of citizens and legal entities, criminal intelligence information, and written explanations of another employee of the National Bureau obtained during an official investigation or inspection of citizens' appeals etc.

The decision to conduct the integrity test is made by the Head of the Department of Internal Control by issuing a permit (The Regulation on the Department 
of Internal Control of the National Anti-Corruption Bureau of Ukraine, 2019). However, as we have already analyzed, we suggest providing a permit for the test by a written resolution of the Head of the Department on the according official note. This decision should be made by the Head of the Department independently without prior notification of the information received his / her line manager, i.e. the Director of the National Bureau, or the line manager of the organization department where the employee of the National Bureau works.

In order to avoid possible preconception of the Head of the Department of Internal Control at making such decision, it should be possible for an employee of the internal control division of the National Bureau to appeal the made decision to the Director of the National Bureau, whose decision would be final.

Moreover, we suggest to implement making an according testing plan as the next stage of procedure the integrity test, because planning of the activities on the integrity test will allow to foresee the possibility of various emergencies, to develop scenarios for a possible set of actions of the Department's worker in order to bring the integrity test to a logical conclusion, prevention of causing property, physical and moral damage both to the participants of the integrity test and to third parties, who became involuntary witnesses or participants in the test.

The plan of the integrity test must be a restricted document and be approved by the Head of the Department. According to our opinion and the results based on the acquaintance with foreign experience of the integrity testing, this document must contain the following information: 1) legal and factual grounds for the test, basically a properly motivated decision of its starting; 2) records about worker or workers of the National Bureau to be tested for integrity; 3) planned actions or a scenario of the integrity test; 4) information about the place of the integrity test conduct; 5) planned date or the period of the integrity test conduct; 6) approximate duration; 7) participants in the integrity test (both employees of the internal control division of the National Bureau, other units, and third parties, involved on a voluntary basis); 8) logistical support of the test; 9) probable scenarios, hypothetical patterns of behavior and variants of actions for those, who conduct and pass the test; 10) actions to prevent possible risks; 11) other information necessary for the test.

The next stage is gathering of the coworkers of the internal control division and, if necessary, other workers of the National Bureau or third parties which are involved in the integrity test to discuss scenario of the integrity test, to assign roles, to determine the range of actions of each participant and to discuss force majeure and an action plan if they occur. Role-playing and training before the integrity test are welcomed. All this makes possible scenarios, probable remarks and actions of the employee of the National Bureau easier to foresee, and in such a way to prevent material or physical damage to the state, legal entities or individuals.

Moreover, the examination of a probable place of conducting the integrity test is carried out, the location of interior items is examined for the possibility of installing audio and video recording devices, the range of people flow is determined, meaning 
the number of people who can be witnesses or involuntary participants in the test and other risks precautions.

The group supervisor of the National Bureau workers, who are conducting integrity test deals with logistical support of the integrity test, determines the test budget, especially if it is necessary to involve third parties in the test conduction, or to purchase or manufacture imitation equipment, carries out measures aimed at calculating the number of audio and video recording devices, their allocation for the integrity test.

Nowadays the issue of audio and video recording of the integrity test is unresolved, although in practice it is obligatory to ensure objectivity and impartiality during the test.

Considering the above mentioned, of course, it is important to codify the provisions on the mandatory audio and video recording of the integrity test and its results. The originals of information that contains audio and video of records must be registered and kept during the statute of limitations, i.e. for three years, in compliance with the relevant confidentiality regime.

The next stage in the procedure of conducting the integrity test is this procedure itself, where a pre-simulated situation is brought into action, a certain scenario where the tested person either complies with the requirements of current legislation or violates them. The mentioned process is completely fixed by audio and video recording. And of course, none of the participants of the test discloses the fact of the integrity test, nor their affiliation with the Department of Internal Control neither during the integrity test, nor immediately after its completion.

After the integrity test, the person, who conducted it, waits for the possibility of removing audio, video recording devices, simulation devices, etc. and after removal ensures their safety.

Based on the results of the integrity test, the person, who conducted it, makes a report, that is the final stage of the integrity test procedure, and which contains the following information: 1) the date of the report composing and the actual integrity test; 2) legal and factual grounds for the test; 3 ) details of the motivated decision of conducting the integrity test; 4) a list of employees of the National Bureau and third parties, who were involved in the integrity test; 5) an employee or employees of the National Bureau who were tested; 6) a description of the measures taken in accordance with the plan of the integrity test and other information on the test; 7) the conduct and actions of the person, who was tested; 8) the list of used imitation equipment, involved audio and video registration, bills, receipts and other documents, which confirm the expenses occurred during the integrity test conduction and the general budget of the integrity test; 9) material losses occurred as a result of the integrity test conduction, such as damaged equipment, imitation equipment, etc., indicating the guilty party of those losses; 10) if any property and non-property damage was caused to an employee of the National Bureau who was tested or to third parties; 11) the result of the integrity test: 
positive or negative; 12) conclusions on vulnerabilities and risks that led employees of the National Bureau to breach their duties; 13) conclusions and substantiated proposals based on the results of the test.

The Head of the Department of Internal Control shall inform the Director of the National Bureau about the results of the test and to submit the report if necessary (The Regulation on the Department of Internal Control of the National AntiCorruption Bureau of Ukraine, 2019). The Director of the National Bureau, in turn, decides on the appointment of an official investigation over this case. The conclusion of the official investigation over this case with the negative result of the integrity test must be handed over to the Disciplinary Commission of the National Bureau to recognize the presence or absence of disciplinary misconduct in the actions of the employee of the National Bureau (The Law of Ukraine "On the National AntiCorruption Bureau of Ukraine", 2014).

\section{Conclusions}

Thus, we have studied the legal (regulatory) and factual (material) grounds for conducting the integrity test of employees of the National Bureau. It is established that the legal (regulatory) basis is, in fact, the legislative permission to conduct the integrity test.

This research also shows that currently there is no proper legal basis for conducting the integrity test of the National Bureau's employees, as the legal grounds for conducting the integrity test in the National Bureau are set out in an internal document, namely the Regulation on the Department of Internal Control of the National Anti-Corruption Bureau of Ukraine, approved by the order of the Director of the National Bureau dated November $29^{\text {th }}, 2019$ by № 142, that is unacceptable because it allows full discretion of the Director of the National Anti-Corruption Bureau of Ukraine and the head of the internal control division in determining the procedure of the integrity test, its grounds, that is an excessive interference with rights and freedoms of the employees of the National Bureau, so the principle of legal certainty is violated at the same time.

We also suggest determining the factual (material) basis for conducting the test as a certain legal fact that causes the necessity for an integrity test by the Department of Internal Control of the National Bureau.

The following factual (material) grounds for the integrity test have been identified: 1) informing an employee of the National Bureau while his appointment about the possible conduction of the integrity test; 2) receiving the information by the employee of the Department of Internal Control of the National Bureau indicating the possibility of non-integrity conduct of the employee of the National Bureau; 3 ) the permission of the Head of the Department of Internal Control for such test (The Regulation on the Department of Internal Control of the National AntiCorruption Bureau of Ukraine, 2019).

The information about possible non-integrity behavior of a particular employee of the National Bureau, received by the Department of Internal Control by phone, 
post, e-mail, determined by an employee of the Department in terms of internal investigation, pre-trial investigation or operative search activity and which takes the form of an according official note with documentary evidences is suggested to be the ground for conducting the integrity test of employees of the National Bureau.

The Regulation on the Department of Internal Control, according to which the Head of the Department of Internal Control provides a written proxy in the form of a relevant resolution for conducting the integrity test has been improved. The introduction of such stage of the integrity test was suggested to be an opportunity to appeal such decision of the head of the internal control division.

The procedure the integrity test of employees of the National Bureau is defined as a legally defined sequence of actions of an employee of the internal control unit of the National Bureau who is empowered to conduct such test, united by the single purpose of testing the integrity of a specific, predetermined employee of the National Bureau.

It is suggested to establish a procedure for the integrity test conduct in a separate section of the Law of Ukraine "On the National Anti-Corruption Bureau of Ukraine", which will consist of the following stages: 1) collection and processing of data on each employee of the National Anti-Corruption Bureau of Ukraine in order to identify any information that may indicate non-integrity behavior; 2) making an official note that includes information about possible non-integrity behavior of a specific employee of the National Bureau with the documentary evidences; 3) making a decision by the Head of the Department of Internal Control on whether to conduct the integrity test or not; 4) appeal or non-appeal of the decision of the Head of the Department by an employee of the Department; 5) composing an integrity test plan; 6) preliminary simulation of the situation by people who will conduct the integrity test; 7) logistical support for the integrity test; 8) the integrity test; 9) a report on the results of the integrity test; 10) informing of the Director of the National Bureau about the results of the integrity test.

In addition, a meaningful content of the integrity test plan and the report on its results are developed.

Thus, it should be noted that the Department of Internal Control of the National Bureau is a pioneer in Ukraine in terms of conducting the integrity test in its classic "New York" sense (Willingham, 2014). At the same time, procedure of the integrity test needs more balanced legislation and further improvement in order to make the use the given tool in the field of anti-corruption among the employees of the National Bureau more effective.

\section{Bibliography:}

1. Звіти про роботу Національного антикорупційного бюро за 2015-2019 роки. URL: https://nabu.gov.ua/reports (дата звернення: 14.07.2020).

2. Інструкція з діловодства у Національному антикорупційному бюро України: наказ Директора Національного бюро від 19.02.2019 № 26. URL: https://nabu.gov.ua/sites/default/ files/page_uploads/25.02/26_nakaz.pdf (дата звернення: 14.07.2020). 
3. Положення про Управління внутрішнього контролю Національного антикорупційного бюро України: наказ Директора Національного антикорупційного бюро України від 29.11.2019 № 142. URL: https://nabu.gov.ua/sites/default/files/page_uploads/02.12/ nakaz_uvk.pdf (дата звернення: 14.07.2020).

4. Про державну службу : Закон України № 889-VIII від 10.12.2015. URL: https://zakon.rada.gov.ua/laws/show/889-19\#Text (дата звернення: 14.07.2020).

5. Про Національне антикорупційне бюро України : Закон України № 1698-VII від 14.10.2014. URL: https://zakon.rada.gov.ua/laws/show/1698-18 (дата звернення: 14.07.2020).

6. Narelle Willingham. 2014. To Undertake Specialized Training in Integrity Testing. Canberra: The Winston Churchill Memorial Trust of Australia. URL: https:/www.churchilltrust.com.au/ media/fellows/To_undertake_specialised_training_in_integrity_testing_N_Beer_2013.pdf. (дата звернення: 14.07.2020).

\section{References:}

1. Zvity pro robotu Natsionalnoho antykoruptsiinoho biuro za 2015-2019 roky. [Reports on the work of the National Anti-Corruption Bureau during 2015-2019 years]. URL: https://nabu.gov.ua/reports (data zvernennia: 14.07.2020). [in Ukrainian]

2. Instruktsiia $\mathrm{z}$ dilovodstva $\mathrm{u}$ Natsionalnomu antykoruptsiinomu biuro Ukrainy: nakaz Dyrektora Natsionalnoho biuro vid 19.02.2019 № 26 [The Instructions on office management in the National Anti-Corruption Bureau of Ukraine: Order of the Director of the National Bureau dated 19.02.2019 № 26]. URL: https://nabu.gov.ua/sites/default/files/page_uploads/25.02/26_ nakaz.pdf (data zvernennia: 14.07.2020). [in Ukrainian]

3. Polozhennia pro Upravlinnia vnutrishnoho kontroliu Natsionalnoho antykoruptsiinoho biuro Ukrainy: nakaz Dyrektora Natsionalnoho antykoruptsiinoho biuro Ukrainy vid 29.11.2019 № 142 [The Regulation on the Department of Internal Control of the National AntiCorruption Bureau of Ukraine: Order of the Director of the National Anti-Corruption Bureau of Ukraine dated November 29, 2019 № 142]. URL: https://nabu.gov.ua/sites/default/files/page_ uploads/02.12/nakaz_uvk.pdf (data zvernennia: 14.07.2020). [in Ukrainian]

4. Pro derzhavnu sluzhbu: Zakon Ukrainy № 889-VIII vid 10.12.2015 [On civil service: Law of Ukraine № 889-VIII of 10.12.2015]. URL: https://zakon.rada.gov.ua/laws/ show/889-19\#Text (data zvernennia: 14.07.2020). [in Ukrainian]

5. Pro Natsionalne antykoruptsiine biuro Ukrainy: Zakon Ukrainy № 1698-VII vid 14.10.2014. [On the National Anti-Corruption Bureau of Ukraine: Law of Ukraine № 1698-VII of 14.10.2014]. URL: https://zakon.rada.gov.ua/laws/show/1698-18 (data zvernennia: 14.07.2020). [in Ukrainian]

6. Narelle Willingham. 2014. To Undertake Specialized Training in Integrity Testing. Canberra: The Winston Churchill Memorial Trust of Australia. URL: https://www.churchilltrust. com.au/media/fellows/To_undertake_specialised_training_in_integrity_testing_N_Beer_2013. pdf. (data zvernennia: 14.07.2020). 


\title{
ЮРИДИЧНА ПРАКТИКА У СФЕРІ АДМІНІСТРАТИВНОГО ПРАВА І ПРОЦЕСУ
}

\section{ПІДСТАВИ ТА ПОРЯДОК ПЕРЕВІРКИ ДОБРОЧЕСНОСТІ ПРАЦІВНИКІВ НАЦІОНАЛЬНОГО АНТИКОРУПЦИЙНОГО БЮРО УКРАЇНИ}

\author{
Олеся Браверман, \\ аспірант кафедри публічного управління та адміністрування \\ Національної академії внутрішніх справ, \\ старший детектив відділу внутрішнього розслідування \\ Управління внутрішнього контролю \\ Національного антикорупційного бюро України \\ orcid.org/0000-0003-0638-6576 \\ o.rybak30@gmail.com
}

Мета-визначити юридичні та фактичні підстави для перевірки доброчесності працівників Національного антикорупиійного бюро Украӥни, сформулювати етапи ицієї процедури.

Методи. Це дослідження було здійснено із застосуванням загальних та спеціальних методів наукового пізнання. За допомогою методів абстракиії, аналізу та синтезу автору вдалося виявити підстави та етапи реалізачії иього явища, відкинувши незначні особливості тесту на иілісність. Діалектичні та логічні методи дозволили з'ясувати суть фактичних та правових підстав для перевірки иілісності, вказати перелік понять. Використовуючи прогнозування та моделювання, автор запропонував конкретну модель правового регулювання підстав та порядку перевірки доброчесності працівників Наиіонального антикорупиійного бюро України.

Результати. У иій статті розглядаються юридичні (нормативні) та фактичні (матеріальні) підстави для перевірки доброчесності прачівників Начіонального бюро. Встановлено, що правовою (регулятивною) підставою є фактично законодавчий дозвіл на перевірку иілісності. Визначення фактичної (матеріальної) підстави для тестування було запропоновано визначити юридичним фактом, який викликає необхідність перевірки доброчесності Департаментом внутрішнього контролю Начіонального бюро. Визначено прочедуру тестування працівників Національного бюро.

Висновки. Наукові дослідження показали, щь зараз відсутні належні правові підстави для проведення перевірки доброчесності працівників Національного бюро, оскільки юридичні підстави для проведення перевірки доброчесності в Начіональному бюро зазначені у внутрішньому документі. Водночас автор вдосконалив фактичні підстави для проведення перевірки иілісності.

Було запропоновано встановити процедуру перевірки доброчесності, яка буде складатися з 10 етапів, в окремому розділі Закону Украӥни «Про Національне антикорупиійне бюро Украйни».

Ключові слова: перевірка цілісності, державна служба, адміністративний контроль, моделювання ситуації, поведінка, що не стосується цілісності. 